\title{
HELYI ADÓZÁS: A SZÜKSÉGES ROSSZ?
}

\author{
Péteri Gábor ${ }^{62}$
}

A helyi önkormányzati rendszer mostani átalakitásakor látszólag egy dolog nem változott: megmaradtak a helyi adók. Söt a helyi költségvetési bevételek között még nött is a súlyuk, mivel a korábbi támogatásigényes önkormányzati feladatok jelentős részét központositották. Valójában azonban a települési adó bevezetésével és a helyi iparüzési adó felhasználásának megkötésével elindult a helyi adók átrendezése.

\section{Az önkormányzati önállóság feltétele a helyi adóbevétel}

De miért is van szükség helyi adókra, milyen egy jól müködő önkormányzati saját bevételi rendszer és hogyan lehetne a hazai helyi iparüzési adó (HIPA) által uralt rendszert továbbfejleszteni?

A helyi önkormányzati finanszírozás 2011 óta folyó átalakítása során a települési adó bevezetése egy gyenge kísérlet volt az elvett személyi jövedelemadó pótlására és a bizonytalan tartalmú feladatfinanszírozás kiegészítésére. Amint Bordás Péter a Közjavak előző számában megjelent, ${ }^{63}$ korábbi tanulmányából már tudjuk, a települési adó visszalépést jelent a helyi adózás 1992 óta müködő rendszeréhez képest. Így nem is véletlen, hogy 2015. január 1-én csak 16 önkormányzat vezette be az új települési adót. ${ }^{64}$ Érdekes módon a területalapú vagy aranykorona érték alapján kivetett termőföld adón kívül néhány önkormányzat azért meglátta benne az új szabályozási lehetőséget. Így a helyi gazdaság ösztönzésére alkalmas lehet a gazdasági övezetbe sorolt, de gazdasági célra nem hasznosított ingatlan területe alapján kivetett települési adó (Kesztölc), vagy az ingatlanadó progresszivitását növelő magas építmények adója (Zsombó).

Valójában azonban a települési adó nagyon hasonlít a három évtizeddel ezelőtti településfejlesztési hozzájáruláshoz (TEHO). Akkor ez a központi tervezési rendszeren kívül eső, szabadon felhasználható helyi bevételi lehetőség nagy ugrás volt a tanácsi pénzügyi önállóság növeléséhez. Persze akkor is tudtuk, hogy ez csak a helyi önállóság érzetét adja meg, de legalább ezen keresztül valamennyire befolyásolni lehetett, hogy hol és mennyi járda épüljön (Gulácsi, 1987).

A helyi adó azonban egy ilyen egyszeri hozzájárulásnál jóval többet jelent. Ma már tudjuk, hogy egy igazán jó helyi saját bevétellel szemben nem csak az az elvárás, hogy aki adót fizet, annak legyenbeleszólása a pénz elköltésének céljaiba is. Alapvető követelmény, hogy az önkormányzat saját feladataihoz viszonyítva a helyi adó jelentôs súlyú legyen, mert csak így képes a támogatásfüggést ténylegesen ellensúlyozni. Ezzel azután már javítható a visszacsatolás a helyben kapott szolgáltatások és a befizetett adók között, ami így erősíti a választott testület és helyi vezetés közvetlen választói-fogyasztói elszámoltathatóságát. Ha a szolgáltatások színvonala, a fejlesztések iránya és mértéke az-önkormányzati döntéshozók „lobbi erejétől” függ, akkor sokkal kevésbé lesznek rajtuk helyben számon kérhetők egy választási ciklus eredményei.

A helyi adókkal szembeni követelmény az is, hogy viszonylag stabil bevételi forrást biztosítsanak úgy, hogy az adóalap és a mentességek meghatározásával ne torzítsák túlzott mértékben a gazdasági szereplők, a piac müködését. Az sem mellékes, hogy milyen

\footnotetext{
${ }^{62}$ Péteri GáborCSc., tanácsadó, LGID Ltd.

${ }^{63}$ BordÁs Péter: Ki mint vet úgy arat, de lesz mit? Gondolatok a települési adó bevezetéséröl. In: Közjavak, 1. évf. 1. szám, 2015 július-szeptember, 29-33.

${ }^{64}$ http://ado.hu/rovatok/ado/helyi-adok-2015-hol-mennyi (letöltés: 2015. december 15.)
} 
költséggel jár a bevezetésük és adóigazgatási szempontból mennyire egyszerüek a helyi adók. A gazdasági hatékonysági szempontok mellett a jó helyi adóknak igazodniuk kell a helyi adófizetési képességhez is. A szociális, kiegyenlítési szempontok is valamennyire mindig beépülnek a helyi adórendszerbe, mert a különböző jövedelmi helyzetű adófizetőknek eltérő mértékben kell hozzájárulniuk a közösségi kiadásokhoz. Egyébként az általában jó helyi adónak tartott ingatlanadóval szemben éppen a degresszivitás az egyik legfontosabb ellenérv - akkor, ha az értékarányos adózáson, beépített jövedelmi fékeken keresztül a progresszivitást nem érvényesíti szabályozás. Ma Magyarországon 49 település kivételével minden önkormányzat kivet valamilyen helyi adót, van amelyik többfélét is.

\section{Miből és hogyan képződik a helyi adóbevétel?}

A gazdaságilag fejlett országokban az állami berendezkedés módjától és a decentralizáció mértékétől függően nagyon változó a helyi adóbevételek jelentősége. A szövetségi rendszerü országokban és az erős helyi önkormányzatokkal rendelkező skandináv országokban a legmagasabb a tagállami-helyi szint részesedése az összes adóbevételből. (1.ábra) Itt a helyi adók aránya meghaladja az összes adóbevétel $30 \%$-át is.

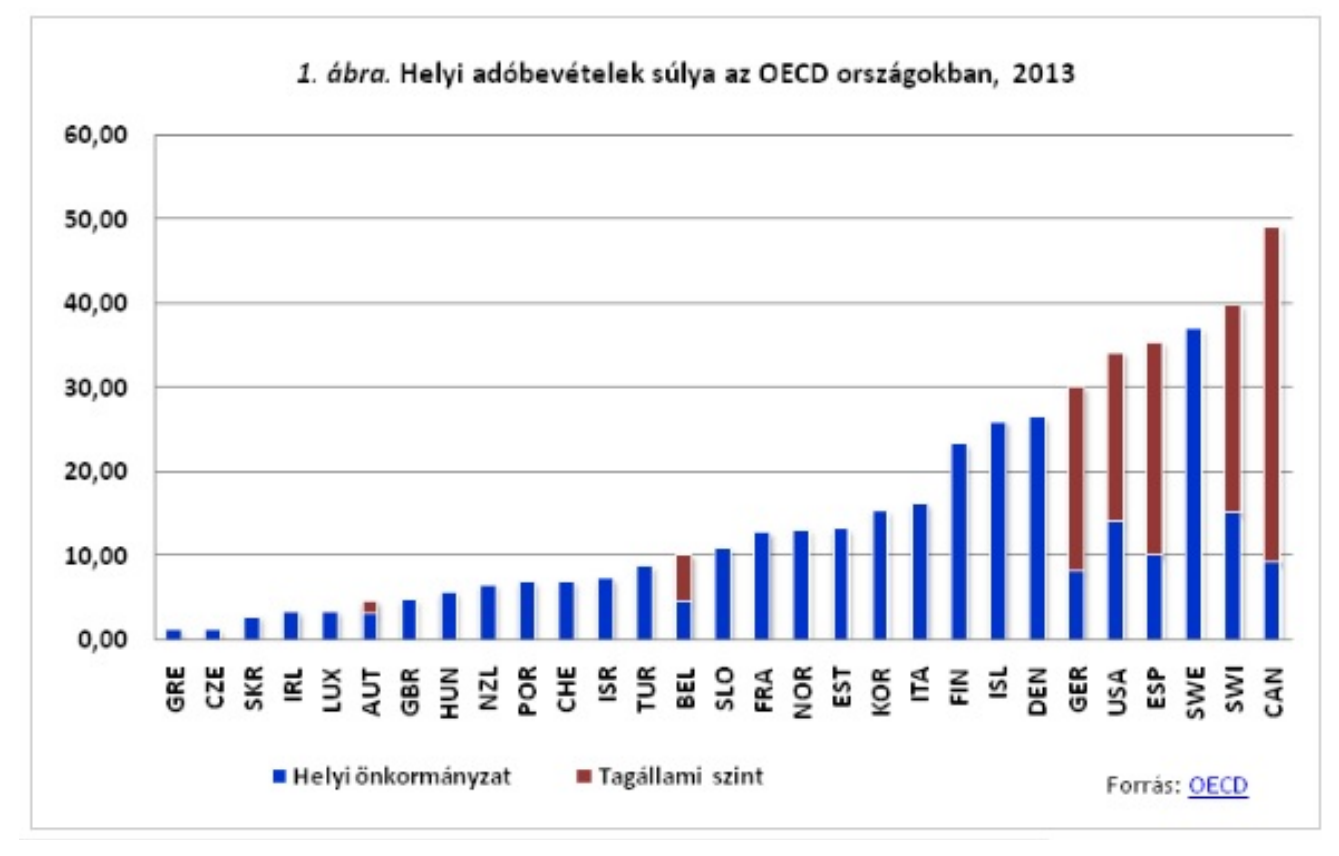

Természetesen a helyi adókivetés soha nem jelent korlátlan önkormányzati autonómiát. Az államháztartás egyensúlyáért, a gazdasági növekedésért, a szociális ellátásért alapvetően a központi kormányzat felelős és így a helyi alrendszer adózási önállósága is szabályozott. Az OECD tagországok átlagából látható, hogy csak a tagállami-regionális szintü önkormányzatok adóbevételeinek többségét (67,5\%) teszik ki azok az adók ahol az adókulcsok és a mentességek megállapításában teljes a helyi önállóság. A második legnagyobb forrás már a forrásmegosztásból származik.

A helyi önkormányzati adóbevételek esetében még inkább szabályozott a forrásképződés: a helyi önállóság még az adókulcsok és a kedvezmények megállapításában is korlátozott (az adóbevételek 41,6\%-a) és az adóátengedés mértéke is - egy vagy több évre vonatkozó központi döntésen múlik. Az adóbevételek megosztása nem feltétlenül jelenti azt, hogy a korábbi magyar SzJA átengedési gyakorlathoz hasonlóan állami támogatásként kerülnek ezek a bevételek a helyi önkormányzatokhoz. Ezek lehetnek közös adóalapra helyi szinten kivetett adók, leggyakrabban személyi jövedelem pótadók. 


\begin{tabular}{|c|c|c|}
\hline \multicolumn{3}{|c|}{ 1. tábla. Helyi adózási autonómia"/ (2011) } \\
\hline & tagállami szint" & helyiönkormányzatok \\
\hline \multicolumn{3}{|l|}{ 1. Helyi önállóság } \\
\hline $\begin{array}{l}\text { (a) az adókulcsok és a mentességek megállapításában } \\
\text { teljes }\end{array}$ & 67,5 & 13,3 \\
\hline korlátozott & - & 0,2 \\
\hline $\begin{array}{l}\text { (o) az adókulcsok és kedvezmények megállapításában } \\
\text { teljes }\end{array}$ & 1,3 & 18,6 \\
\hline korlátozott & 4,9 & 41,6 \\
\hline (c) mentessćgck megállapításában & - & 0,0 \\
\hline \multicolumn{3}{|l|}{ 2. Forrásmegosztás } \\
\hline (d1) helyi döntés & - & 0,0 \\
\hline (d2) helyı onkormannyzatck egyetèrtèsėvel & $1 /, 2$ & 1,1 \\
\hline (d3) központilag, több év`e & 0,5 & 8,7 \\
\hline (d4) központi, évente & - & 3,4 \\
\hline $\begin{array}{l}\text { (e ) Központi az adókulcsok és a mentességek } \\
\text { megállapítása }\end{array}$ & 6,0 & 5,7 \\
\hline (f) Egyéb & 2,6 & 6,8 \\
\hline Összesen & 100,0 & 100,0 \\
\hline Összes államháztartási adóbevétel \%-a & 16,6 & 10,6 \\
\hline
\end{tabular}

Főleg a skandináv országokban valamint a térségünkben Horvátországban és Montenegróban alkalmazzák ezt a fajta adómegosztási módszert. Természetesen itt is törvény által meghatározott minimális és maximális adókulcsok között vetik ki a közös adóalapra az önkormányzatok saját adójukat. Ez a fajta kormányzati szintek közötti adómegosztás növeli a helyi és a központi kormányzat egymásra utaltságát és erősíti a közszolgáltatási feladatok ellátásában a két szint közös felelősségét. A forrásmegosztás egyben hatásos költségvetési szabályozási eszköz, mert automatikusan követi a megosztott bevételeket alakító gazdasági folyamatokat. A helyi, területi és a központi kormányzat együtt élvezik a növekvő adóalap előnyeit illetve az esetleges veszteségeket is előre látható és szabályozott módon osztják meg. A helyi adózási modellek abból a szempontból is eltérnek, hogy mi képezi az adó alapját. Az angolszász országokban (és Franciaországban) jellemző az értékalapú ingatlanadózás, míg máshol valamilyenjövedelem helyi adóztatása terjedt el. Ezeken keresztül teremthetö meg ugyanis legjobban a kapcsolat vagyontárgyak értéke, vagy az egyéni, vállalkozói jövedelmek és a helyi közszolgáltatások színvonala között. Az ingatlan típusú helyi adók mellett szóló érv, hogy az adóalap helyhez kötöttsége miatt jobban tervezhető és elősegíti a közigazgatási határokon túlnyúló szolgáltatások finanszírozását is. Bár mint a 2008. évi gazdasági válság után látható volt az értékalapú helyi ingatlanadó bevételek is jelentősen visszaeshetnek, ha egy térség gazdasága hirtelen összeomlik és így az adóalapot képező ingatlanok leértékelődnek. A helyi adózási rendszerek közötti választást alapvetően az adózási, adóigazgatási hagyományok is meghatározzák, ezért a váltás csak fokozatos lehet.

A jelentős helyi adókivetési önállóság elleni érvként merülhet fel még az önkormányzati adóversenykedvezötlen hatása. Elméletileg a központi és a helyi szint közötti verseny kiüresítheti a közös adóalapot, míg az önkormányzatok között pedig egyfajta adóminimalizálási versenyt indíthat el a mozdítható adótárgyak esetében. Az elemzések azonban azt igazolták, hogy valójában a fejlett országok esetében a helyi adók inkább nőnek,mint csökkennek és a különböző országokban a helyi adókulcsok közelítenek egymáshoz. Kormányzati adópolitikával korlátok között tartható az adóverseny, például az 
ingatlanadók szerepének erősítésével, az adóalapok egységesítésével és célzott kiegyenlítési politikákkal. ${ }^{65}$

\section{Helyi iparúzési adó és társai}

A magyar helyi önkormányzati saját bevételek több mint felét teszik ki a helyi adók. A helyi adótörvény által kínált lehetőségek közül az önkormányzatok leggyakrabban az ingatlanokhoz (vagyon, kommunális) kapcsolódó adót vetették ki, de a helyi adóbevételek négyötöde mégis a helyi iparüzési adóból származik. A magyar gazdaság területi koncentrációjából következően az 500 milliárd forintnyi helyi iparűzési adó közel negyven százaléka Budapesten képződik. (2.tábla) A megyei jogú városokban és a többi város helyi adóbevételi részesedése egy-egy negyed. Így a maradék $10 \%$ jut a nagyközségi-községi önkormányzatoknak.

\begin{tabular}{|c|c|c|}
\hline \multicolumn{3}{|c|}{ 2.tábla Helyi iparũzési adóbevétel településtípusonként (2013) } \\
\hline & $\begin{array}{c}\text { HIPA összege } \\
\text { (M Ft) }\end{array}$ & $\begin{array}{l}\text { Egy före jutó HIPA az } \\
\text { országos átlag \%-ában }\end{array}$ \\
\hline Fơváros & 99554,6 & $118 \%$ \\
\hline Fővárosi kerület & 95650,5 & $113 \%$ \\
\hline Megyei jogú város & 113084,2 & $113 \%$ \\
\hline Város & 140650,9 & $88 \%$ \\
\hline Nagyközség & 10231,9 & $43 \%$ \\
\hline Község & 42065,8 & $32 \%$ \\
\hline Összesen & 501237,8 & $100 \%$ \\
\hline
\end{tabular}

Mivel a fővárosi HIPA bevétel meghatározó súlyú, az egy főre jutó adóbevételek is jelentősen eltérnek. Itt az országos átlagnál jóval magasabb a Főváros és a kerületek között nagyjából fele-fele arányban megosztott helyi iparüzési adóbevétel. A megyei jogú városok fajlagos adóbevétele magasabb még mint az országos átlag, majd fokozatosan csökken a helyi iparüzési bevételi kapacitás. A területi adatokból a nyugat-kelet irányú területi különbségek is jól láthatók ${ }^{66}$

A helyi iparüzési adóból jelentős önkormányzati bevétel származik, ezért minden város és egy kivétellel az összes nagyközség kiveti. Viszont községeknek csak a 86\%-a látta értelmét bevezetni a HIPA-t, mert a többi helyen feltehetően hiányzik az adóalap, vagy nem lenne jelentős a befolyó bevétel.

A helyi iparüzési adó városi túlsúlya miatt viszonylag hamar beépült a pénzügyi kiegyenlítési rendszerbe. A lakóhelyre visszajuttatott személyi jövedelemadóval együtt a helyi adókapacitás mérésére szolgált, amit a normatív állami támogatások számításánál csökkentő tényezőként vettek figyelembe. A mai önkormányzati feladatfinanszírozási rendszer pedig a beszámítás fenntartása mellett az ellátandó feladatokhoz (a szociális ellátáshoz, sőt a tervek szerint a fóvárosban atömegközlekedési feladatokhoz) köti a helyi iparüzési bevételt. ${ }^{67}$

\footnotetext{
65 BlÖCHLIGER-CAMPOS: TaxCompetitionBetweenSub-CentralGovernments, OECD, 2011, Elérhető: http://www.oecd-ilibrary.org/taxation/tax-competition-between-sub-central-governments 5k97b1120t6b-en (letöltés: 2015. december 15.)

${ }^{66}$ HORVÁTH - PÉTERI - VÉCSI:A helyi forrásszabályozási rendszer magyarországi példája, 1990-2012. Közgazdasági Szemle, LXI. évf. 2014. február, 121-147.

${ }^{67}$ http://www.parlament.hu/irom40/08196/08196.pdf (letöltés: 2015. december 15.)
} 
A gazdaság helyi megadóztatása Európa más országaiban is már régóta müködik. Iparüzési adó típusú helyi adórendszerek voltak például Franciaországban, Németországban, Olaszországban. Általában a termelési tényezők (eszközök, munkabér) valamilyen kombinációjára vetik ki a helyi iparüzési adót. Az olasz helyi iparüzési adó (IRAP) a vállalkozások nettó jövedelemére kivetett helyi vállalkozói adó. Éppen ezért úgy tünt, ütközik az Európai Unió helyi ÁFA-t tiltó elöírásaival, de végül is nem kellett megszüntetni, mivel a termelés nettó értékének kiszámítása másképpen történik és így nem tekinthető hozzáadott érték alapú adónak. ${ }^{68}$

A 2008-as válság után a gazdaság-élénkítő politika részeként több országban átalakult a gazdaság helyi adóztatási rendszere. Franciaországban megszünt a helyi iparüzési adó (taxprofessionnelle), bár felváltották más ingatlanadó típusú és hozzáadott érték alapú helyi forrásokkal. Németországban is a termelési tényezők közül a személyi kiadásokra kivetett rész csökkent, az eszközökre (épületekre, berendezésekre) épülő rész eltünt és föleg nagyvállalatok esetében alkalmazzák.

Ebből is látható, hogy a több évtizedes múlttal rendelkező helyi adórendszerek modernizálása nehéz feladat. Különösen azért népszerüek a helyi politikusok körében az üzleti forgalomhoz kapcsolódó adók, mert az adófizetéshez nem kapcsolódik közvetlenül helyi választói képviselet. Így azután az önkormányzati elszámoltathatóság is csak korlátozottan müködik. Bár sérül az adóztatás azon alapelve, amely szerint nem lehet adóztatni képviselet nélkül, a helyi hozzáadott érték típusú adók tulajdonképpen a helyi infrastruktúra használatáért fizetendő általános vállalkozói díjnak tekinthetők. A helyi adófizető beazonosítható, az üzleti forgalom mértéke kapcsolódik az infrastruktúra terheléséhez, a központi adóigazgatásra ráépülhet a helyi. ${ }^{69}$ Így tehát a politikailag kevéssé kockázatos helyi adó mellett is szólnak érvek. A Magyarországon is meglévő területi és város-falu közötti különbségeket pedig máshol úgy próbálják megoldani, hogy a nagyobb terület egységeken belül népességarányosan, vagy más módon újraosztják a térségben-városkörnyékben képződött helyi iparüzési adót.

Jelentős helyi adóbevétel nélkül,mint tudjuk,az önkormányzatiság sem müködik. A magyar helyi adózást a korábbi működés tapasztalatai alapján tovább kell fejleszteni. Erre három irányban van lehetőség: (i) a HIPA esetében be kell építeni a rendszerbe (kis)térségi szempontot, amikor a települési önkormányzatok közösen döntenek a helyi iparüzési adó mértékéröl és elosztásáról, (ii) az értékalapú ingatlanadózás elterjesztése a helyi adóigazgatás támogatható és (iii) elvileg adott az SzJA helyi pótadóztatás,mint a sajátos helyi adózás lehetősége is.

Viszont a helyi önkormányzati rendszer 2011 óta folyó leépítésének áldozatul esett a magyar helyi adózási rendszer is. Így a mai önkormányzati és finanszírozási rendszerben a helyi adózás szakmai szempontok alapján történő átalakításának egyre kisebb a realitása.

\footnotetext{
${ }^{68}$ A C-475/03. sz. ügy,

http://curia.europa.eu/juris/document/document.jsf?text $=\&$ docid $=65390 \&$ pageIndex $=0 \&$ doclang $=$ hu\&mode $=1$ st \&dir=\&occ $=$ first\&part $=1 \&$ cid $=1057055$ (letöltés: 2015 . december 15 .)

${ }^{69}$ BIRD, Richard M.: The VAT as a Local Business Tax. Reprinted fromTaxNotesInt'l, November 4, 2013, p. 453.

Elérhető:http://www.iticnet.org/images/72ti0453-bird.pdf (letöltés: 2015. december 15.)
} 